\title{
イオンビーム照射法拈よび高周波スパッタリング法によって 作製した窒化チタン薄膜の表面構造*
}

\author{
閔敬烈**. 笠原 章**.吉原 一紘** \\ ホフマン シーグフリード**.志水 隆一***
}

（受理1996年11月 30 日，掲載決定1997年 3 月 1 日）

Surface Structure of Titanium Nitride Prepared by Ion Beam

Irradiation and RF Sputtering Processes

Kyung-youl MIN, Akira KASAHARA, Kazuhiro YOSHIHARA

Siegfried HOFMANN and Ryuichi SHIMIZU

**(National Research Institute for Metals, 1-2-1, Sengen, Tsukuba, Ibaraki)
***(Faculty of Engineering, Osaka University, 2-1 Yamadaoka Suita, Osaka)

(Received November 30, 1996, Accepted March 1, 1997)

\section{1. はじめに}

窒化チタン薄膜はその優れた機械的，電気的特性によ り様々な面で広く応用されている. しかし, この様な活 発な工業的な応用にもかかわらず，その膜の形成原理に ついては，まだ未知の所が多い。今まで我々は, 超高真 空中で薄膜を作製しながらその薄膜の成長過程を調べる ために, 反射高速電子回折 (RHEED) イオン散乱分光 （ISS）が備えた装置を開発し，研究を行ってきた1). 本 研究では上記の実験装置を用い,イオンビーム照射法に おケるイオンのドーズ量変化に伴う薄膜の表面構造につ いて調べ，その結果を検討した。また，実際的な薄膜製 作に広く応用されている高周波スパッタリング法を用 い, 成膜時に窒素とアルゴンガスの両方を取り入れるこ とにより混合ガスの比率を変え, 作製される薄膜の表面 構造の変化との相関性を調べた.

\section{2. 実験}

\section{1 イオンビーム照射法}

実験はまず， $\mathrm{Si}(001)$ 基板上に電子線衝撃型蒸着源に

\footnotetext{
* 平成 8 年 11 月 1 日 第 37 回真空に関する連合講演会で講演

** 金属材料技術研究所 (厂305つくば市千現 1-2-1)

*** 大阪大学工学部 (宁565 吹田市山田丘 2-1)
}

よって厚さ約 $50 \mathrm{~nm}$ のチタン膜を予め蒸着し, その上に $3 \mathrm{keV}$ の窒素イオンビームを照射しながら表面の結晶性 の変化をRHEEDを用いて観察した.イオンビームの 直径は $2 \mathrm{~mm}$, 密度は $2 \times 10^{13} \mathrm{~N}_{2}^{+}$ions $/ \mathrm{cm}^{2} \cdot \mathrm{sec}$ であっ た．装置のベース圧力は $1.3 \times 10^{-7} \mathrm{~Pa}$ ，イオンビーム照 射時の圧力は約 $2.7 \times 10^{-6} \mathrm{~Pa}$ であった.

\section{2 高周波スパッタリング法}

実験には高純度のアルゴンガス (99.99\%) 及び窒素 ガス $(99.995 \%)$ を用い，アルゴンガスの供給量を固定 して窒素ガスの供給量を変えることにより，二つの混合 ガス比率を変化させ，チタンを $\mathrm{Si}(111)$ 基板上に蒸着す る際の吸着窒素の量を変えた。な拉，用いたチタンター

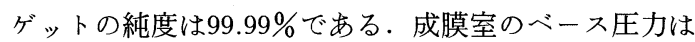
約 $1.3 \times 10^{-5} \mathrm{~Pa}$ であり，成膜中のガス圧力は $5.3 \times 10^{-1}$ $\mathrm{Pa}$ に固定した.チタンターゲットから基板までの距離 を50 mm とし, 窒素とアルゴン混合ガスの比率を変え ながら 2 時間で成膜した。

\section{3. 実験結果及び考察}

\section{1 イオンビーム照射法}

Fig. 1 の RHEED パタンーはイオンビーム照射法に よって作製した窒化チタン薄膜の窒素イオンビーム照射 時間に伴ら表面結晶配向の変化を示す. 図から分かるよ 
(a)

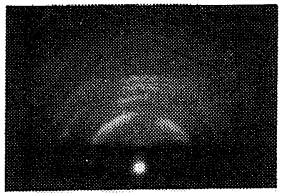

(b)

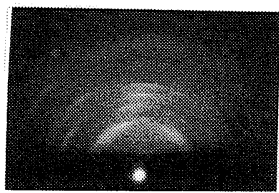

(c)
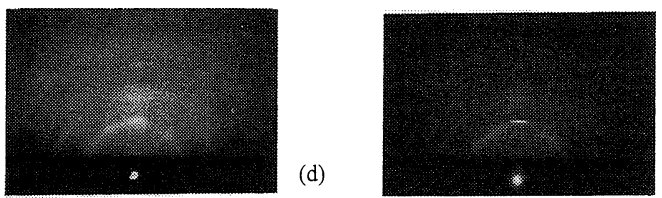

(d)

Fig. 1 The change of surface structures by nitrogen ion beam irradiation. RHEED patterns indicate the structures of (a) before irradiation, (b) ca. $3 \times 10^{15}$ $\mathrm{N}_{2}^{+}$ions $/ \mathrm{cm}^{2}$, (c) ca. $5 \times 10^{15} \mathrm{~N}_{2}^{+}$ions $/ \mathrm{cm}^{2}$, (d) ca. $3 \times 10^{16} \mathrm{~N}_{2}^{+}$ions $/ \mathrm{cm}^{2}$, (e) ca. $1 \times 10^{17} \mathrm{~N}_{2}^{+}$ions $/ \mathrm{cm}^{2}$.

らに, 初期段階では(110) 優先配向の窒化チタンパター ンを示すが，イオンビーム照射を続けると(110)優先配 向は弱くなって，(100)優先配向のパターンが強くなる. 図では窒化チタンのパターン以外飞, 周辺部分にリング パターンが見光るが，これはRHEED 電子ビームが斜 め照射され，イオンビームが当たっていない部分からの チタンパターンが出現するためである.

一般的に, 反応性スパッタリング法やイオンビーム支 援蒸着法（Ion Beam Assisted Deposition, IBAD）では, 反応室に混入する窒素の量が蒸着されるチタンの量より 大きくなると，作製される窒素チタン薄膜は(111)から (100)優先方向に変わる2)。これを説明するためには， まずチャンネリング効果といらモデルが考兄られる3). このモデルによると，(100)配合の結晶構造が(100)配向 よりその成長速度が速く，また(111)結晶構造が(100)よ り密であることから，あるエネルギーを持つ窒素を成長 する薄膜に混入する際，(111) 構造は破壊されやすく， 結果的に (100)構造の方が残存する. しかし, このモデ ルが正しいとすれば(100)構造も(111) 構造も成長する が, 成長するにつれて(111) 構造のみが破壊されて行く ことになるが，我々の前回の実駼結果では初期過程から その配向性が一つに決まって成長されていくことを確認 している1).

次に考光られるモデルとしては, 最近, Pelleg らが提

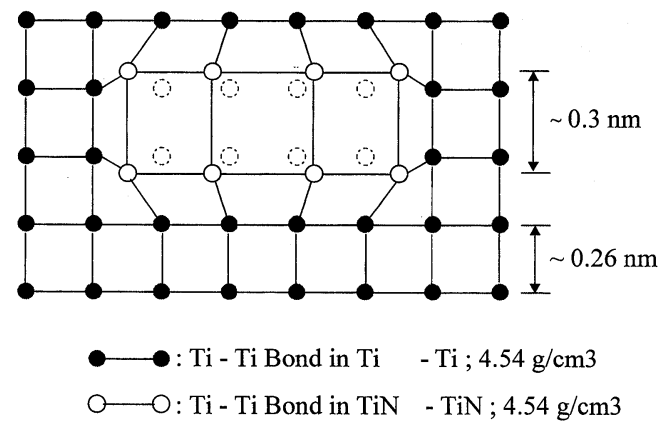

Fig. 2 The schematic diagram of the structures of titanium and titanium nitride. Tensile stress of deposited titanium nitride film is released by nitrogen beam irradiaton.

案している全エネルギーモデルが挙げられる4)。このモ デルによると, 窒化チタン薄膜の優先配向は薄膜表面で の表面エネルギーとひずみェネルギーとの相関関係によ って決まる。即ち, 薄膜の全エネルギー（ $W_{\mathrm{hkl}} ）$ は表面 エネルギー $\left(S_{\mathrm{hkl}}\right)$ とひずみェネルギー $\left(U_{\mathrm{hkl}}\right)$ によって 記述でき, 表面エネルギーは表面で切断された場合の数 によって $S_{111}>S_{110}>S_{100}$ のようになり，ひずみエネルギ 一は TiG の結果から計算して, $U_{100}>U_{110}>U_{111}$ のよう になっていることを見出している.

この関係から，(100)優先配向の場合はひずみエネル ギーより表面エネルギーの方が主になり, 逆に(111)優 先配向の場合はひずみェネルギーが主になっているよら 飞考光られる. 彼らのモデルの実験対応の説明では薄膜 に加わるストレスは成膜時の高周波パワーの変化による として, 高いパワーの時は(111)の優先配向が成長し, 低い時は(100)配向になるとしている。な抏，Je ら5) ら 上記のモデルを実際に実験に応用して確認しているが， 一般的に成膜時のパワーが変化すれば薄膜成長に打ける スパッタ率の变化等複雑な現象が起こり, 直接的に混入 する窒素の量と蒸着するチタンの量との関係を結び付け にくい.

今回我々の結果から, 照射される窒素イオンのドーズ 量が増兄るにつれて (110)優先配向から (100) 優先配向に 変わっていることにより, イオンドーズ量と表面結晶構 造との相関性が分かる．これを説明するため，つぎのよ らに上記の全エネルギーモデルを考光てみる.今回の結 果では(111)優先配向の成長は確認できなかったが，こ れは膜成長の初期段階で形成された(111) 配向が直ぐ (110)配向飞変わったため, 今回実験で用いた RHEED の測定では観測出来なかったと思われる．以下では，実 験結果が示している(110)配向と(100)配向との比較で考 


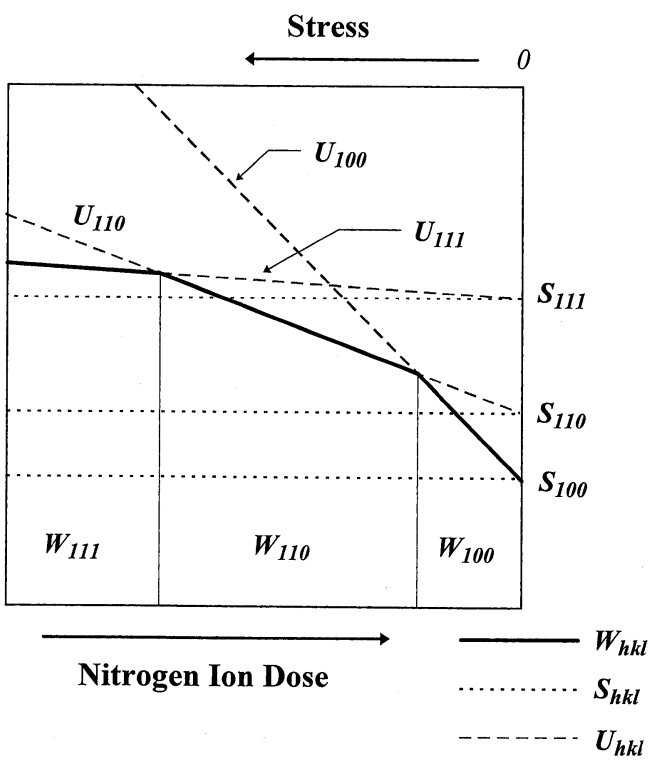

Fig. 3 The schematic illustration of structural change of titanium nitride film by nitrogen ion irradiation supposing the total energy is composed of surface and stress energies.

察する.

蒸着されたチタン薄膜は蒸着時の基板温度変化によっ て Si 基板とチタンとの線膨張係数の違いにより張力歪 みを示す。この様なチタン薄膜へ窒素イオンビームを照 射し窒化チタンを形成すると，Fig. 2 に示すようにチタ ン金属での $\mathrm{Ti}-\mathrm{Ti}$ 原子間距離より窒化チタンでの $\mathrm{Ti}-$ $\mathrm{Ti}$ 原子間距離がより大きいことから，窒素とチタンの 結合が増えるにつれて最初に薄膜に存在していた張力歪 みが緩和される、つまり，薄膜成長初期段階でのひずみ エネルギーが主になっていた(110)優先配向の窒化チタ ン構造から表面エネルギーが主になる(100)優先配向に 変わる. 注入した窒素イオンとチタンとの強い結合によ る窒化チタン薄膜の成長についてはすでに報告した6).

Fig. 3 に照射されるイオンビームのドーズ量変化に伴ら 膜のストレス変化によって記述される窒化チタン薄膜の 配向性変化を模式的に示す.

\section{2 高周波スパッタリング法}

Fig. 4 に異なる窒素とアルゴン混合ガスの比率によっ て作製した窒化チタン薄膜の X 線回折結果 (a)及び XPS 分析結果 (b)を示す. X 線回折結果は窒素ガスの比 率により窒化チタン薄膜の結晶配向が (100) 優先配向か ら (111) 優先配向に変わるが，窒素ガスの比率が 1 より 大きくなると再び $(100)$ 優先配向になることを示す.

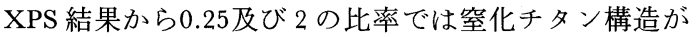

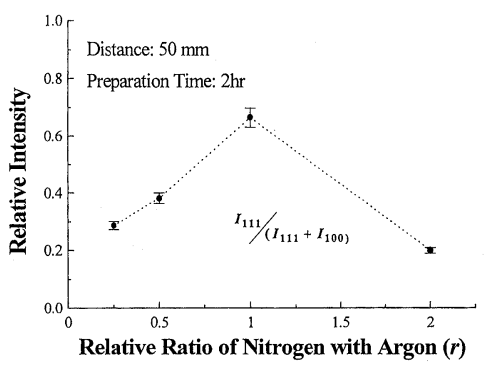

(a)

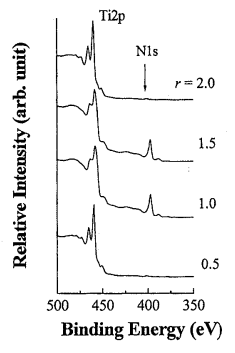

(b)
Fig. 4 The changes of structure and surface composition of titanium films by the concentration of mixing gases.

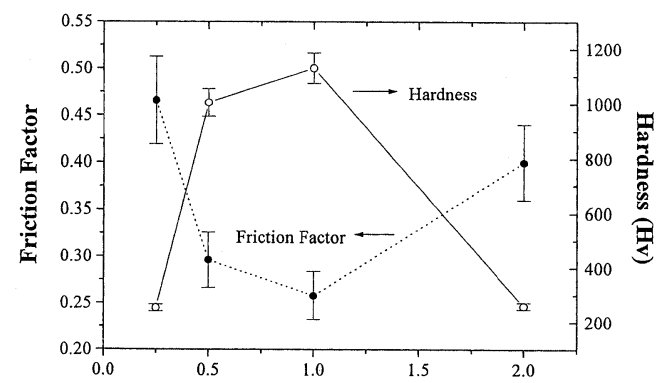

Relative Ratio of Nitrogen with Argon

Fig. 5 The changes of friction coefficient and hardness of titanium nitride films by the concentration of mixing gases.

少ないことが分かる. 特に 0.5 及び 1 の比率の場合を比 ベてみると，1の方が 0.5 の場合より X 線ピークの半值 幅から定性的に見積もった結晶粒大きさに起因する歪み が約30\%減っていることが分かった．この結果は蒸着さ れる薄膜に扣いて窒素とチタンの比率により窒素が多く なるとストレスが低くなるとい5 Fig. 3 で示した結果 と一致する。

Fig. 5 は上記の条件で作製した薄膜の摩擦係数及び硬 度変化を示す．窒化チタン構造が多く形成されている 0.5 の比率及び(111) 優先配向になっている 1 の比率で は, 膜の結晶構造がより密であることから低い摩擦係数 及び高い硬度を示していると思われる。

\section{4. 結言}

今回我々は，イオンビーム照射法拉よび高周波スパッ タリング法によって作製した窒化チタン薄膜の表面構造 について研究を行い，薄膜の表面エネルギーおよびひず みエネルギーによる全エネルギーモデルと薄膜の結晶配 
向性との相関関係について考察した，また，高周波スパ ッタリング法によって作製した薄膜は(111)優先配向を 示す方がより低い摩擦保数及び高い硬度を示しているこ とが分かった．今回の研究では膜の厚さを調べなかった が，薄膜の実際的な応用のために，基板と膜の界面作用 による摩擦係数及び硬度变化について研究を進める予定 である。

\section{〔文献〕}

1）閔 敬烈: Study on Surface Modification by Ion Beam Processing, 大阪大学工学部学位論文, 1995.
2) M. Satou, K. Fujii, M. Kiuchi and F. Fujimoto: Nucl. Instrum. \& Methoods B39 (1989) 166.

3) M. Kiuchi, A. Chayahara, Y. Horino, K. Fujii, M. Satou, H. J. Kang, Y. W. Beag, Y. Kimura and R. Shimizu: Jpn. J. Appl. Phys. 29 (1990) 2059.

4) J. Pelleg, L. Z. Zevin and S. Lungo: Thin Solid Films, 197 (1991) 117.

5) U. C. Oh and J. H. Je: J. Appl. Phys. 74 (1993) 1692.

6) K. Min, Y. Suzuki, R. Mitsuhashi, M. Inoue, R. Shimizu and S. Hofmann: Jpn. J. Appl. Phys., 35 (1996) 221. 